\title{
Hepatitis C in the Brazilian public health care system: burden of disease
}

\author{
Adauto CASTEL01, Carlos Eduardo BRANDÃO MELLO², Rosangela TEIXEIRA ${ }^{3}$, \\ Jose Valdez Ramalho MADRUGA ${ }^{4}$, Tania REUTER ${ }^{5}$, Leila Maria Moreira Beltrão PEREIRA ${ }^{6,7}$, \\ Giovanni Faria SILVA ${ }^{8}$, Mario Reis ÁLVARES-DA-SILVA ${ }^{9}$, Heverton ZAMBRINI ${ }^{10}$ and \\ Paulo Roberto Abrão FERREIRA ${ }^{1}$
}

Received 26/3/2018 Accepted 15/8/2018

ABSTRACT - Background - Infection by hepatitis C virus is one of the leading causes of chronic hepatitis $\mathrm{C}$ and cause severe burden for patients, families and the health care system. Objective - The aims of this research were to assess the severity of liver fibrosis, comorbidities and complications of hepatitis $\mathrm{C}$ virus; to examine health-related quality of life (HRQoL), productivity loss and resource use and costs in a sample of Brazilian chronic hepatitis $\mathrm{C}$, genotype 1, patients. Methods - This was a cross-sectional multicenter study performed in genotype-1 chronic hepatitis $\mathrm{C}$ patients to assess disease burden in the Brazilian public health care system between November 2014 and March 2015. Patients were submitted to a liver transient elastography (FibroScan) to assess liver fibrosis and answered an interview composed by a questionnaire specifically developed for the study and three standardized questionnaires: EQ-5D-3L, HCV-PRO and WPAI:HepC. Results - There were 313 subjects enrolled, with predominance of women (50.8\%), caucasian/ white $(55.9 \%)$ and employed individuals (39.9\%). Mean age was $56(\mathrm{SD}=10.4)$ years old. Moreover, $42.8 \%$ of patients who underwent FibroScan were cirrhotic; the most frequent comorbidity was cardiovascular disease (62.6\%) and the most frequent complication was esophageal varices $(54.5 \%)$. The results also showed that "pain and discomfort" was the most affected HRQoL dimension (55.0\% of patients reported some problems) and that the mean HCV-PRO overall score was 69.1 ( $\mathrm{SD}=24.2)$. Regarding productivity loss, the most affected WPAI:HepC component was daily activity $(23.5 \%)$ and among employed patients, presenteeism was more frequent than absenteeism $(18.5 \% \mathrm{vs} 6.5 \%)$. The direct medical costs in this chronic hepatitis C sample was 12,305.72USD per patient in the 2 years study period; drug treatment costs represented $95.9 \%$ of this total. Conclusion - This study showed that most patients are cirrhotic, present high prevalence of cardiometabolic diseases and esophageal varices, reduced HRQoL mainly in terms of pain/discomfort, and work productivity impairment, especially presenteeism. Additionally, we demonstrated that hepatitis $\mathrm{C}$ virus imposes an economic burden on Brazilian Health Care System and that most of this cost is due to drug treatment.

HEADINGS - Hepatitis C. Liver cirrhosis. Quality of life. Cost of illness.

\section{INTRODUCTION}

Infection by hepatitis $\mathrm{C}$ virus (HCV) is one of the leading causes of chronic liver disease; however, the majority of the infected individuals is not diagnosed. It is estimated that there are approximately 170-200 million people infected globally and 2.5 million people in Brazil $^{(1-4)}$.

The prevalence of HCV genotypes vary across countries ${ }^{(5)}$. Given Brazil's continental size, it is expected that this prevalence also varies among regions. A comprehensive study enrolling 1,688 sequential samples from chronic HCV patients found a statistical significant difference regarding patterns of genotypes distribution among regions $(P=0.00017)$. However, genotype 1 was the most frequent in all regions, ranging from $51.7 \%$ in the South to $74.1 \%$ in the $\operatorname{North}^{(6)}$.

HCV symptoms may include malaise, weakness, anorexia, and jaundice, although the illness rarely causes acute symptomatic infection $^{(7)}$. There is a lot of evidence showing that hepatitis $\mathrm{C}$ can lead to persistent infection in a high proportion of infected individuals, and it can progress to chronic liver disease, cirrhosis, and hepatocellular carcinoma $(\mathrm{HCC})^{(8)}$. Chronic hepatitis $\mathrm{C}(\mathrm{CHC})$ causes severe burden for patients, families, and the health care system, once the economic implications include not only costs related to disease management, but also consequences of productivity loss ${ }^{(4-9)}$. It is estimated that $\mathrm{CHC}$ is responsible for approximately 350,000 deaths per year in United States ${ }^{(10)}$.

In Brazil, Ministry of Health provides access to HCV treatment since 2002, following a National Guideline applied only to the Brazilian public healthcare system that includes interferon or pegylated interferon, ribavirin, sofosbuvir, simeprevir, daclatasvir and ombitasvir/veruprevir/ritonavir plus dasabuvir ${ }^{(11-14)}$. Patients receiving those therapies through government funding need to be attending a public medical facility specialized in HCV treatment. Other therapies not currently available in this National Guidelines can be obtained in the private setting through health insurance coverage or as a patient out-of-pocket expense ${ }^{(13)}$.

Disclosure of funding: AbbVie Farmacêutica

${ }^{4}$ Universidade Federal de São Paulo, Escola Paulista de Medicina, São Paulo, SP, Brasil. ${ }^{2}$ Universidade Federal do Estado do Rio de Janeiro, Hospital Universitário Gaffrée e Guinle, RJ, Brasil. ${ }^{3}$ Universidade Federal de Minas Gerais, Faculdade de Medicina, Belo Horizonte, MG, Brasil. ${ }^{4}$ Centro de Treinamento e Referência DST/Aids, São Paulo, SP, Brasil. ${ }^{5}$ Hospital Universitário Cassiano Antonio de Moraes, Vitória, ES, Brasil. 6 Instituto do Fígado e Transplante de Pernambuco, Recife, PE, Brasil. 7 Universidade de Pernambuco, Recife, PE, Brasil. 8 Universidade Estadual Paulista, Faculdade de Medicina, Botucatu, SP, Brasil. ${ }^{9}$ Universidade Federal do Rio Grande do Sul, Hospital de Clínicas de Porto alegre, RS, Brasil. ${ }^{10}$ AbbVie, São Paulo, SP, Brasil. Corresponding author: Heverton Zambrini. Orcid: 0000-0003-2589-8163. Email: heverton.zambrini@abbvie.com 
Thus, the aims of this report were to describe the severity of liver fibrosis, comorbidities and complications of $\mathrm{HCV}$; healthrelated quality of life (HRQoL), productivity loss and resource use and costs for the public healthcare system, in a sample of Brazilian Chronic Hepatitis C, genotype 1, patients, as investigated in a multicenter study focused on treatment patterns and disease burden.

\section{METHODS}

\section{Study design}

This was a cross-sectional multicenter study investigating genotype-1 $\mathrm{CHC}$ patients to assess treatment patterns and burden of hepatitis $\mathrm{C}$ in the Brazilian public healthcare system between November 2014 and March 2015. The study was conducted in eight specialized centers in CHC treatment located in Southeast (Cities: Belo Horizonte, Botucatu, Rio de Janeiro, São Paulo, and Vitória), South (City: Porto Alegre), and Northeast (City: Recife) Brazilian regions. Patients were submitted to a liver transient elastography (FibroScan) to assess liver fibrosis grade, according to METAVIR score ${ }^{(15)}$, and to an interview composed by a questionnaire specifically developed for the study and three standardized questionnaires: Euroqol 5-Dimension Questionnaire 3 level version (EQ-5D-3L ${ }^{(16)}$, Hepatitis $\mathrm{C}$ virus patient-reported outcomes instrument (HCVPRO) ${ }^{(17)}$, and HCV-specific Work Productivity and Activity Impairment (WPAI:HepC) $)^{(18)}$.

\section{Subject selection, recruitment and inclusion}

Patients were randomly selected to be invited to the study screening process from a list of $\mathrm{CHC}$ patients who have attended at least one outpatient visit within the year before the study initiation, as provided by the study sites. Patients ranked by alphabetic ordered were numbered, then a computer generated random number list was used to select patients for screening. The selected patients received a phone call inviting to participate in the study. The patients willing to participate had a study visit scheduled to receive detailed information about the study protocol, signing the informed consent, and initiating the study procedures. Eligible patients were those with diagnosis of $\mathrm{CHC}$ genotype 1 as described in medical charts, with at least one outpatient visit during the year previous to study enrollment and aged at least 18 years old. Patients unable to provide informed consent, answer the interview and/or patients who had been enrolled in a clinical trial were excluded.

\section{Data sources and collection methods}

The structured interview included questions about sociodemographic and clinical characteristics, and consumption of out-of-pocket resources using a recall period of 12 months prior to inclusion in the study, except for medicines that considered a recall period of three months. Information about medical resources utilization, comorbidities and complications were abstracted from medical charts. Outpatient and hospital resources related to $\mathrm{HCV}$ and its complications were collected for a recall period up to 24 months prior to study entry. If the FibroScan test could not be performed at the same day as the interview, a second study visit with a maximum interval of eight weeks was scheduled.

To assess quality-of-life and function and well-being of patients, the following instruments were used, respectively: EQ-5D-3L and HCV-PRO. The EQ-5D-3L is a generic instrument assessing health status through five domains (mobility, self-care, usual activities, pain/discomfort, and anxiety/depression). Each dimension has three levels: no problems, some problems, extreme problems, accordingly, $3^{5}=243$ combinations of health states are possible. Each of the health states was converted into a utility score between 0 and 1 (representing a scale between death $=0$ and perfect health $=1$ ), using the United Kingdom algorithm which was the standard reference at the time of the study protocol preparation ${ }^{(16,19)}$. The questionnaire also includes a Visual Analogue Scale (VAS-EQ) which records respondent's self-rated health, according to endpoints labeled from "Best imaginable health state" to "Worst imaginable health state"(16). The HCV-PRO is a specific instrument that measures the effects of the disease upon function and well-being. It contains 16 items about how often an experience or limitation was perceived, with levels of response choices ranging from $1=$ all of the time to $5=$ none of the time. The total score is the conversion of 16 results into a 0-100 scale. A greater HCV-PRO total score indicates greater levels of function and well-being ${ }^{(17)}$.

The WPAI:HepC measures the effects of hepatitis $\mathrm{C}$ on productivity in the workplace and beyond. It is a questionnaire that contains four questions and from these questions it is possible to derivate four domains: percentage of work time missed due to illhealth (absenteeism), percentage of impairment while working due to ill-health (presenteeism), percentage of overall work impairment due to ill-health (absenteeism and presenteeism), and percentage of daily activity impairment due to ill-health. These domains are converted into a $0-100 \%$ scale where high percentages represent more impact on productivity ${ }^{(18)}$.

Costs were estimated by multiplying the amount of consumed resources (as self-reported by patients or abstracted from medical charts) for their unit costs. The unit costs sources of tests, outpatient visits, non-drug treatments, and emergency room visits were SIGTAP (System List of Procedures Management, Medicines, Prosthetics and Orthotics, and Specialty Materials of SUS; competency - December, $2015)^{(20)}$. The unit cost of hospitalizations/surgical treatments were obtained in SIH (Hospital Information System; competency - 2014) of SUS - Unified Health System ${ }^{(21)}$. The unit costs of drugs were firstly searched in BPS (Health Prices Database) ${ }^{(22)}$ by the lowest and latest purchase price accessible; if the unit cost was not available in BPS, the maximum selling price allowed for Government purchases (PMVG ICMS 0\%) in the CMED (Medication Market Regulation Chamber - December 18, 2015) ${ }^{(23)}$ list was used. The reasons for emergency room visits, hospitalizations, and surgical treatments were classified according to International Statistical Classification of Diseases and Related Health Problems 10th Revision (ICD-10) ${ }^{(24)}$. Tests were classified according to Clinical Protocol and Therapeutic Guidelines for Hepatitis C and Coinfections (PCDT) ${ }^{(25)}$, and drugs according to Anatomical Therapeutic Chemical (ATC) $\operatorname{code}^{(26)}$. The unit costs were obtained between December, 2015 and January, 2016 and all data prices were collected in Brazilian Real (BRL) and then converted into American dollar values (USD) using the exchange rate of the date of consultation to the price list (16/Jan/2016), where $1.00 \mathrm{BRL}$ corresponded to $0.2479 \mathrm{USD}$.

\section{Sample size calculation}

This analysis is a part of a larger study designed to estimate the frequency of any specific HCV therapy in the sample (treatment pattern). The original sample size calculation had the purpose to detect a frequency of at least 10\% of the triple therapy (pegylated interferon, ribavirin, telaprevir or boceprevir) recommended for HCV patients with METAVIR F3-F4 (that represents 33\% of 
the total population of HCV patients, according to Poynard et al. $\left.{ }^{(27)}\right)$. Thus, considering an assumed distribution of triple therapy among all $\mathrm{HCV}$ patients of $3 \%(10 \%$ of $33 \%)$, a margin of error of $3.0 \%$, and $\alpha=0.05$, a sample of $318 \mathrm{HCV}$ patients was required. However, 313 patients were included in the study, which provided a $95 \%$ confidence interval $(\mathrm{CI})$ with a margin of error of $3.3 \%$. The data presented here are related to secondary outcomes of the aforementioned study.

\section{Statistical analysis}

The descriptive analysis was performed through tabulation measures of central tendency (mean) and dispersion (standard deviation-SD) to quantitative variables, and frequency to qualitative variables. The analyses were conducted using Stata (version MP $12^{\circledR}$ ) and R Project (version 3.1.2 ${ }^{\circ}$ ) to provide a $95 \% \mathrm{CI}$ and $P$-value $\leq 0.05$.

\section{Ethical approval}

The research was reviewed and approved by Brazilian Independent Ethics Committees of each participating site (Supplementary material 3). The coordinator center approval was obtained in September 12, 2014 (Comitê de Ética em Pesquisa do CRT DST/ Aids, no. 789.165). All procedures were in accordance with the ethical standards of the institutional and national research committee and with the Helsinki declaration and its later amendments or comparable ethical standards.

\section{RESULTS}

\section{Sample characterization}

Three hundred and eighteen patients were considered potentially eligible; however, five patients did not meet inclusion criteria, resulting in 313 subjects enrolled. TABLE 1 shows the sociodemographic characteristics among included patients. The sample was mainly composed by females $(50.8 \%)$, Caucasian/white $(55.9 \%)$ and employed $(39.9 \%)$. Mean age was $56(\mathrm{SD}=10.4)$ years old and the predominant educational level was complete high school $(29.1 \%)$. Only $1.6 \%$ and $6.4 \%$ of sample presented coinfection $\mathrm{HCV} /$ hepatitis B virus (HBV) and HCV/human immunodeficiency virus (HIV), respectively.

\section{Liver fibrosis severity, comorbidities and complications}

Cirrhosis was present in $42.8 \%$ of HCV patients who underwent FibroScan (FIGURE 1). Cardiovascular (62.6\%), metabolic $(50.5 \%)$, and mental $(23.8 \%)$ diseases were the most frequent comorbidities, while esophageal varices $(54.5 \%)$ and portal hypertension $(43.6 \%)$ were the most frequent complications (TABLE 1).

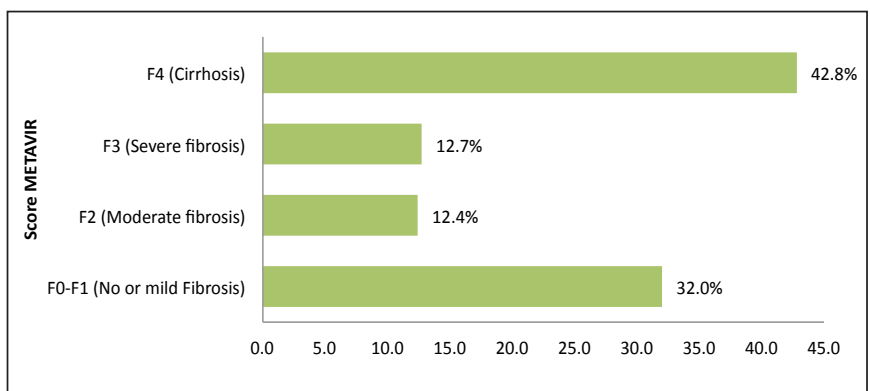

FIGURE 1. FibroScan test results according to METAVIR score $(\mathrm{N}=306)$.
TABLE 1. Sociodemographic and clinical characteristics of $\mathrm{HCV}$ patients.

\begin{tabular}{|c|c|c|}
\hline Characteristic & $\mathbf{N}$ & $\%$ \\
\hline \multicolumn{3}{|l|}{ Age $(\mathrm{N}=313)$} \\
\hline $18-29$ years old & 1 & 0.3 \\
\hline $30-39$ years old & 25 & 8.0 \\
\hline $40-49$ years old & 54 & 17.3 \\
\hline $50-59$ years old & 101 & 32.2 \\
\hline$\geq 60$ years old & 132 & 42.2 \\
\hline \multicolumn{3}{|l|}{ Gender $(\mathrm{N}=313)$} \\
\hline Female & 159 & 50.8 \\
\hline Male & 154 & 49.2 \\
\hline \multicolumn{3}{|l|}{$\operatorname{Race}(\mathrm{N}=313)$} \\
\hline Caucasian/White & 175 & 55.9 \\
\hline Brown & 96 & 30.7 \\
\hline Black & 39 & 12.5 \\
\hline Oriental & 2 & 0.6 \\
\hline Indigenous & 1 & 0.3 \\
\hline \multicolumn{3}{|l|}{ Educational level $(\mathrm{N}=313)$} \\
\hline No education & 3 & 1.0 \\
\hline Incomplete elementary school & 76 & 24.3 \\
\hline Complete elementary school & 50 & 16.0 \\
\hline Incomplete high school & 33 & 10.5 \\
\hline Complete high school & 91 & 29.1 \\
\hline Incomplete graduation & 22 & 7.0 \\
\hline Complete graduation & 25 & 8.0 \\
\hline \multicolumn{3}{|l|}{ Employment $(\mathrm{N}=313)$} \\
\hline Employed & 125 & 39.9 \\
\hline Retired & 97 & 31.0 \\
\hline Unemployed & 72 & 23.0 \\
\hline Pensioner & 5 & 1.6 \\
\hline Autonomous & 4 & 1.3 \\
\hline Absent from work & 4 & 1.3 \\
\hline Student & 3 & 1.0 \\
\hline NI & 3 & 1.0 \\
\hline \multicolumn{3}{|l|}{ Comorbidities $(\mathrm{N}=206)$} \\
\hline Cardiovascular diseases & 129 & 62.6 \\
\hline Metabolic diseases & 104 & 50.5 \\
\hline Mental disorders & 49 & 23.8 \\
\hline Extrahepatic manifestations & 7 & 3.4 \\
\hline Coagulation disorders & 7 & 3.4 \\
\hline Hepatocellular carcinoma & 3 & 1.5 \\
\hline Cryoglobulinemia & 2 & 1.0 \\
\hline Late cutaneous porphyria & 1 & 0.5 \\
\hline Other $^{\mathrm{a}}$ & 39 & 18.9 \\
\hline \multicolumn{3}{|l|}{ Complications $(\mathrm{N}=55)$} \\
\hline Esophageal varices & 30 & 54.5 \\
\hline Portal hypertension & 24 & 43.6 \\
\hline Splenomegaly & 20 & 36.4 \\
\hline Thrombocytopenia & 20 & 36.4 \\
\hline Ascitis & 10 & 18.2 \\
\hline Other liver diseases & 9 & 16.4 \\
\hline Hepatic encephalopathy & 5 & 9.1 \\
\hline Bleeding esophageal varices & 4 & 7.3 \\
\hline Hepatocellular carcinoma & 4 & 7.3 \\
\hline Spontaneous bacterial peritonitis & 1 & 1.8 \\
\hline Hepatorenal syndrome & 1 & 1.8 \\
\hline Other ${ }^{\mathrm{b}}$ & 7 & 12.7 \\
\hline
\end{tabular}

${ }^{a}$ Adenocarcinoma infiltrative of large intestine, leg amputation, sickle cell anemia, asthma, severe asthma, breast cancer, cirrhosis, cholelithiasis, chemical dependency, neuropathic pain, gastroesophageal reflux, epilepsy, hepatoesplenic schistosomiasis form, hepatic steatosis, fibromyalgia, antral erosive moderated gastritis associated with $H$. pylori, supraumbilical hernia, hemangioma, urinary incontinence, peripheral venous insufficiency, chronic renal insufficiency, lactose intolerance, labyrinthitis biliary lithiasis, myoclonus of soft palate, nefrolithiasis, neurocysticercosis, neurotoxoplasmosis, pangastritis, psoriasis, ulcerative colitis, syphilis, pulmonary sarcoidosis, esophageal varices, vitiligo. ${ }^{b}$ Lower limb edema, esophagitis, hyperferritinemia, icterus, cutaneous vasculitis. 


\section{Health-Related Quality of Life (HRQoL)}

There were 305 valid responses for EQ-5D-3L. "Pain and discomfort" and "anxiety and depression" were the dimensions with highest HRQoL impairment, in which $55.0 \%$ and $47.0 \%$ of patients reported to have problems, respectively. "Self-care" was the least affected dimension, with $95.0 \%$ of responders reporting absence of problems (FIGURE 2). The mean overall EQ-VAS score was 75.1 (SD 21.4). Patients who reported problems to perform usual activities also presented the lowest score in this dimension according to EQ-VAS - TABLE 2.

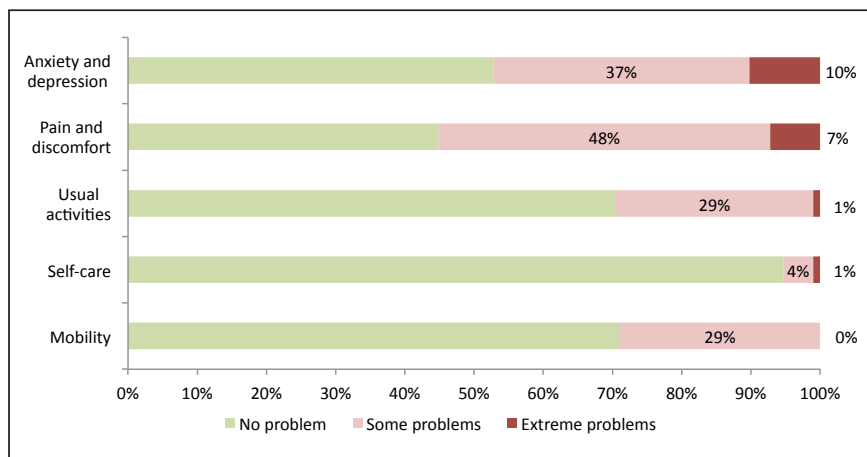

FIGURE 2. Limitations in health-related quality of life among HCV patients according EQ-5D-3L dimensions $(\mathrm{N}=305)$.

TABLE 2. Results of the Visual Analog Scale (EQ-VAS) among HCV patients according to EQ-5D dimensions $(\mathrm{N}=305)$.

\begin{tabular}{lcccccc}
\hline \multirow{2}{*}{ Dimensions } & \multicolumn{2}{c}{$\begin{array}{c}\text { No } \\
\text { Problems }\end{array}$} & \multicolumn{2}{c}{$\begin{array}{c}\text { Some } \\
\text { Problems }\end{array}$} & \multicolumn{2}{c}{$\begin{array}{c}\text { Extreme } \\
\text { Problems }\end{array}$} \\
\cline { 2 - 7 } & Mean & SD & Mean & SD & Mean & SD \\
\hline Mobility & 80.6 & 19 & 60.8 & 20.9 & - & - \\
Self-care & 76.1 & 20.6 & 60.6 & 20.5 & 50.3 & 30.5 \\
Usual activities & 82.2 & 17.2 & 58.8 & 21.1 & 39.3 & 17.6 \\
$\begin{array}{l}\text { Pain and } \\
\text { discomfort }\end{array}$ & 86.6 & 13.5 & 68.5 & 20.8 & 47.5 & 23.5 \\
$\begin{array}{l}\text { Anxiety and } \\
\text { depression }\end{array}$ & 84.9 & 14.4 & 67.2 & 20.7 & 53.9 & 26.4 \\
$\begin{array}{l}\text { Overall Score } \\
\text { 0-100 [mean/SD] }\end{array}$ & 75.1 & {$[21.4]$} & & & & \\
\hline
\end{tabular}

\section{Function and well-being}

The mean HCV-PRO overall score was 69.1 ( $\mathrm{SD}=24.2)$. The dimensions presented similar mean scores. The most affected items in patients' perception were those regarding "tiredness" $(\mathrm{Q} 1$. mean $=3.4 ; \mathrm{SD}=1.3)$ and "sleep" $(\mathrm{Q} 15$. mean $=3.4 ; \mathrm{SD}=1.5)$

- TABLE 3.

\section{Productivity loss}

The productivity loss results showed that $79.9 \%$ of patients were currently remunerated, $12.4 \%$ of patients stopped working due to hepatitis $\mathrm{C}$, and the mean age of work interruption was 49.7 $(\mathrm{SD}=9.5)$ years old. $\mathrm{HCV}$ caused temporary and permanent income reductions for $11.2 \%$ and $5.6 \%$ of employed patients, respectively. In addition, $14.4 \%$ of patients needed a sick leave in the past 12 months due to hepatitis $\mathrm{C}$, of whom $61.1 \%$ received sick leave paid benefits (TABLE 4).
TABLE 3. Mean scores of HCV-PRO questions among HCV patients $(\mathrm{N}=313)$.

\begin{tabular}{|c|c|c|}
\hline Question & Mean & $\mathrm{SD}$ \\
\hline $\begin{array}{l}\text { Q1. I feel too tired during the day to get done } \\
\text { what I need }(1-5)\end{array}$ & 3.4 & 1.3 \\
\hline $\begin{array}{l}\text { Q2. I have to pace myself to finish what I had } \\
\text { planned (1-5) }\end{array}$ & 3.7 & 1.4 \\
\hline Q3. I feel forced to spend time in bed (1-5) & 4.1 & 1.1 \\
\hline Q4. My muscles feel weak (1-5) & 3.7 & 1.4 \\
\hline Q5. During the day, I cannot get comfortable (1-5) & 3.7 & 1.2 \\
\hline $\begin{array}{l}\text { Q6. I am unable to think clearly or focus on my } \\
\text { thoughts }(1-5)\end{array}$ & 4.0 & 1.2 \\
\hline Q7. I am forgetful (1-5) & 3.5 & 1.2 \\
\hline $\begin{array}{l}\text { Q8. Having hepatitis } C \text { has affected my sex life } \\
(1-5)\end{array}$ & 3.9 & 1.4 \\
\hline $\begin{array}{l}\text { Q9. I feel bothered by pain or physical discomfort } \\
(1-5)\end{array}$ & 3.5 & 1.4 \\
\hline $\begin{array}{l}\text { Q10. Because of my hepatitis } C \text {, I find it hard to } \\
\text { meet people or make new friends }(1-5)\end{array}$ & 4.5 & 1.2 \\
\hline $\begin{array}{l}\text { Q11. Having this illness is very stressful to me } \\
(1-5)\end{array}$ & 3.6 & 1.4 \\
\hline Q12. I feel downhearted and sad (1-5) & 3.5 & 1.4 \\
\hline Q13. I feel restless or on edge (1-5) & 3.9 & 1.3 \\
\hline Q14. I feel little interest in doing things (1-5) & 3.7 & 1.3 \\
\hline $\begin{array}{l}\text { Q15. I have had difficulty sleeping or sleeping too } \\
\text { much }(1-5)\end{array}$ & 3.4 & 1.5 \\
\hline Q16. Hepatitis C lowers my quality of life (1-5) & 3.7 & 1.5 \\
\hline Overall score $(0-100)$ & 69.1 & 24.2 \\
\hline
\end{tabular}

TABLE 4. Productivity loss among HCV patients $(\mathrm{N}=313)$.

\begin{tabular}{|c|c|c|}
\hline Productivity Loss & & \\
\hline Patients currently remunerated ${ }^{\text {a }}$ & $\mathrm{N}(\%)$ & $250(79.9)$ \\
\hline Stopped working due to hepatitis C & $\mathrm{N}(\%)$ & $39(12.4)$ \\
\hline Age of work interruption & USD (mean/SD) & $49.7(9.5)$ \\
\hline $\begin{array}{l}\text { Permanent income reduction caused } \\
\text { by HCV }\end{array}$ & $\mathrm{N}(\%)$ & $7(5.6)$ \\
\hline $\begin{array}{l}\text { Monthly income before the } \\
\text { permanent reduction }\end{array}$ & USD (mean/SD) & $\begin{array}{c}974.99 \\
(1,023.31)\end{array}$ \\
\hline $\begin{array}{l}\text { Monthly income after the } \\
\text { permanent reduction }\end{array}$ & USD (mean/SD) & $\begin{array}{c}508.20 \\
(481.15)\end{array}$ \\
\hline $\begin{array}{l}\text { Need of sick leave in the last } 12 \\
\text { months }\end{array}$ & $\mathrm{N}(\%)$ & $18(14.4)$ \\
\hline $\begin{array}{l}\text { Temporary income reduction caused } \\
\text { by HCV in the last } 12 \text { months }\end{array}$ & $\mathrm{N}(\%)$ & $14(11.2)$ \\
\hline $\begin{array}{l}\text { Monthly income before the } \\
\text { temporary reduction }\end{array}$ & USD (mean/SD) & $\begin{array}{l}707.46 \\
(412.28)\end{array}$ \\
\hline $\begin{array}{l}\text { Monthly income after the } \\
\text { temporary reduction }\end{array}$ & USD (mean/SD) & $\begin{array}{c}428.82 \\
(233.72)\end{array}$ \\
\hline
\end{tabular}


There were 312 valid responses for WPAI:HepC. The most affected component was daily activity $(23.5 \%)$. Among employed patients, presenteeism was more frequent than absenteeism (18.5\% vs $6.5 \%$ ) and the overall work impairment was $15.9 \%$.

\section{Health care resource use and cost}

- Out-of-pocket (OOP) expenses

TABLE 5 shows that $40.3 \%$ of patients had private health insurance. The average monthly cost of health insurance was USD 90.71 per patient. The cost component with highest annual cost was visits with other health care professionals (mean=USD 562.11 per patient). Besides, only $11.5 \%$ of patients had OOP expenses with medicines in the past three months. The mean OOP cost of medicines in this period was USD 42.66.

TABLE 5. Out-of-pocket medical resources due to hepatitis $\mathrm{C}(\mathrm{N}=313)$.

\begin{tabular}{|c|c|c|}
\hline Resources & $\mathbf{N}$ & $\%$ \\
\hline Private health insurance & 126 & 40.3 \\
\hline $\begin{array}{l}\text { Acquisition of private health insurance due } \\
\text { to hepatitis c }(n=126)\end{array}$ & 10 & 7.9 \\
\hline \multicolumn{3}{|l|}{$\begin{array}{l}\text { Monthly expenses with health care insurance } \\
(\mathrm{mean} / \mathrm{sd})\end{array}$} \\
\hline USD & 90.71 & 52.26 \\
\hline Medical tests in the past 12 months & 60 & 19.2 \\
\hline \multicolumn{3}{|l|}{ Expenses with tests (mean/sd) } \\
\hline USD & 170.36 & 258.29 \\
\hline Medical visits in the past 12 months & 21 & 6.7 \\
\hline \multicolumn{3}{|l|}{ Expenses with visits (mean/sd) } \\
\hline USD & 194.97 & 274.90 \\
\hline $\begin{array}{l}\text { Visit with other health care professional in the } \\
\text { past } 12 \text { months }\end{array}$ & 12 & 3.8 \\
\hline \multicolumn{3}{|l|}{ Expenses with visits (mean/sd) } \\
\hline USD & 562.11 & 671.81 \\
\hline Medicines in the past 3 months & 36 & 11.5 \\
\hline \multicolumn{3}{|l|}{ Expenses with medicines (mean/sd) } \\
\hline USD & 42.66 & 40.63 \\
\hline
\end{tabular}

Regarding non-medical expenses related to hepatitis $\mathrm{C}$, all resources had low frequency of use among patients, except for the need of transportation in the past 12 months $(93.9 \%)$. The mean number of trips was $11.3(\mathrm{SD}=14.9)$ and each travel costed USD 8.83 on average (TABLE 6).
TABLE 6. Non-medical resources due to hepatitis $\mathrm{C}(\mathrm{N}=313)$.

\begin{tabular}{lcc} 
Resources & N & $\%$ \\
\hline Need of assistant in the past 12 months & 23 & 7.3 \\
Housekeeper/Nanny & 17 & 65.3 \\
Caregiver & 1 & 4.3 \\
Driver & 2 & 8.7 \\
Other* & 4 & 17.4
\end{tabular}

Expenses with assistant in the past 12 months $(\mathrm{mean} / \mathrm{SD})$

USD

$163.19 \quad 141.95$

Need of support equipment in the past 12 months

$\begin{array}{cc}4 & 1.3 \\ 2 & 50.0 \\ 1 & 25.0 \\ 1 & 25.0\end{array}$

Expenses with support equipment in the past 12 months (mean/SD)

USD

$166.09 \quad 128.56$

Home adaptations in the past 12 months

$\begin{array}{ll}7 & 2.2\end{array}$

Grab rails

$\begin{array}{ll}6 & 85.7\end{array}$

Air conditioner

$1 \quad 14.3$

Stair

Bedroom remodeling

14.3

Ramps

14.3

28.6

Expenses with home adaptations in the past 12 months (mean/SD)

USD

$339.97 \quad 331.59$

Need of transportation in the past 12 months

Number of travels to the hospital due to hepatitis $C$ in the past 12 months (mean/SD)

$11.3 \quad 14.9$

Expenses in each travel (mean/SD)

USD

8.83

23.25

*General Helper, Assistant, Seller, Mason.

\section{- Healthcare system expenses}

The total direct medical costs with this $\mathrm{CHC}$ sample were USD 3,851,691.23 for the past two years, which represented USD $12,305.72$ per patient in the 2-year study period (per capita annual costs of USD 6,152.85-TABLE 7). Drug treatment accounted for $95.9 \%$ of the total costs. 
TABLE 7. Cost according to each type of health care resource used by HCV patients in the last 2 years.

\begin{tabular}{|c|c|c|c|c|c|c|}
\hline \multirow{3}{*}{ Resource } & \multicolumn{2}{|c|}{ Patient $(\mathrm{N}=313)$} & \multicolumn{3}{|c|}{ Cost (USD) } & \multirow{3}{*}{ Cost $(\%)$} \\
\hline & \multirow{2}{*}{$\mathbf{N}$} & \multirow{2}{*}{$\%$} & \multicolumn{2}{|c|}{ Per patient } & \multirow{2}{*}{ Total } & \\
\hline & & & Mean & SD & & \\
\hline Drug treatment & 179 & 57.2 & $20,636.76$ & $26,681.42$ & $3,693,980.03$ & 95.9 \\
\hline Directly related to $\mathrm{HCV}$ & 111 & 62.0 & $32,410.11$ & $27,483.02$ & $3,597,522.34$ & 93.4 \\
\hline Not-directly related to HCV & 147 & 82.1 & 656.17 & $1,643.84$ & $96,457.69$ & 2.5 \\
\hline Test & 307 & 98.1 & 244.43 & 170.45 & $75,041.13$ & 1.9 \\
\hline Hospitalization/Surgery & 16 & 5.1 & $4,499.92$ & $8,954.80$ & $71,998.73$ & 1.9 \\
\hline Outpatient visit & 313 & 100.0 & 33.22 & 28.73 & $10,397.27$ & 0.3 \\
\hline Physician & 313 & 100.0 & 28.58 & 23.96 & $8,945.47$ & 0.2 \\
\hline Other health care professional & 128 & 40.9 & 11.34 & 14.61 & $1,451.80$ & $0.0 *$ \\
\hline Non-drug treatment & 19 & 6.1 & 9.71 & 13.39 & 184.42 & $0.0 * *$ \\
\hline
\end{tabular}

$* 0.037 . * * 0.004 . * * * 0.002$

\section{DISCUSSION}

Accurate assessment of liver fibrosis stage has important implications for prognostic, monitoring purposes and is essential for a rational therapeutic decision-making in hepatitis $\mathrm{C}^{(28)}$. FibroScan results showed that most of our sample had cirrhosis. Thus, it is reasonable to consider that most Brazilian $\mathrm{HCV}$ patients attending $\mathrm{CHC}$ specialized centers have indication to antiviral treatment and require interventions to control known negative cofactors for disease progression. These include life style modifications, as weight loss, alcohol and drug abstinence ${ }^{(28)}$.

There are scarce data regarding the prevalence of liver fibrosis stages determined by FibroScan in Brazil. In fact, our frequencies of severe fibrosis and cirrhosis were much higher than results found by Fernandes et al. Those authors conducted a study in $120 \mathrm{CHC}$ patients and reported the following findings: $54 \%, 30 \%, 9 \%$, and $7 \%$ for METAVIR stages F0F1, F2, F3, and F4, respectively ${ }^{(29)}$. Even considering some false positive results of FibroScan or the higher frequency of severe patients in our sample due to the fact that the study sites are specialized centers to where high complexity patients are referred to, it is possible that this higher prevalence of cirrhosis is related to a progressively worse scenario of liver fibrosis among Brazilian patients.

Regarding comorbidities, the frequencies of $\mathrm{HCV} / \mathrm{HBV}$ and HCV/HIV confections in our sample were lower than those observed in previous Brazilian studies ${ }^{(30,31)}$. In a study performed by Carvalho-Filho et al. ${ }^{(30)}$ with $581 \mathrm{CHC}$ patients, 59 (10.2\%) individuals had HIV coinfection and 31 (5.3\%) had HBV coinfection. Both frequencies were higher than observed in the present study. Another study, carried out by Moia et al. in HCV patients, found a prevalence of HCV/HIV coinfection more than two-fold higher than the one described in this sample $(23.9 \%)^{(31)}$.

$\mathrm{HCV}$ has significant hepatic implication, however it has also been involved in derangements of multiple other organ systems including the muscular, skeletal, nervous, endocrine, cardiovascular, respiratory, and urinary systems ${ }^{(32)}$. The most common comorbidities in our study were those related to cardiovascular, metabolic and mental diseases, which is consistent with literature $\operatorname{data}^{(31,33-36)}$.

Previous studies have addressed the role of $\mathrm{HCV}$ infection on cardiovascular-related complications ${ }^{(34,36)}$, and suggest a strong relationship between $\mathrm{HCV}$ infection and the atherogenic process, with high risk of coronary heart disease, carotid atherosclerosis, peripheral artery disease and, ultimately, cardiovascular-related mortality ${ }^{(36)}$. Regarding metabolic diseases, evidences suggest that $\mathrm{HCV}$ interference with glucose and lipid metabolism leads patients to acquire diabetes more frequently ${ }^{(35,36)}$. Also, $\mathrm{CHC}$ present considerable psychological burden, particularly depression and anxiety ${ }^{(33,37)}$, which justifies the presence of mental disorders as a frequent comorbidity.

The EQ-5D-3L index found in the present study was 0.733 [SD 0.28] and is consistent with previously researches conducted in France ( 0.764 [SD 0.283]) and Canada ( 0.76 for patients with non-cirrhotic chronic $\mathrm{HCV}, 0.74$ for patients with compensated cirrhosis, and 0.66 for patients with decompensate cirrhosis) ${ }^{(38,39)}$.

Andrade and collaborators conducted a study using EQ-5D-3L in Brazilian general population. The descriptive analysis showed the following frequencies of patients that presented no problems: mobility $(91.23 \%)$, self-care $(97.59 \%)$, usual activities $(89.85 \%)$, pain/discomfort (57.71\%) and anxiety/depression $(64.92 \%)^{(40)}$. Thus, except for self-care, HCV patients seem to present higher impairment in HRQoL in all EQ-5D-3L dimensions as compared to the Brazilian general population.

More than $10 \%$ of our sample stopped working due to hepatitis C. The mean age of work interruption was 10 years earlier than the regular age of retirement in Brazil for women and 15 years earlier for men. Current literature confirms that $\mathrm{CHC}$ patients experience increased work productivity impairment ${ }^{(41,42)}$. Besides, our data suggested that presenteeism seems to be more relevant than absenteeism in CHC patients. A similar result was found by DiBonaventura et al. in a European study involving CHC patients ${ }^{(42)}$.

Drugs for CHC are part of the Drug Dispensing Program of the Brazilian Ministry of Health, but are also purchased by 
State Departments of Health ${ }^{(43)}$. Therefore, the introduction of new costly technologies implies an economic impact on multiple levels of medical care in the Brazilian healthcare system. In this scenario, real-world data on $\mathrm{CHC}$ costs are extremely relevant to support planning and funding of HCV management strategies, for example highlighting disease aspects that are more costly and can be addressed by effective treatment and monitoring, reducing the overall $\mathrm{CHC}$ cost for the society.

The HCV per capita annual costs in the present cohort was USD 6,152.85 (BRL 4,819.93). These costs were higher than direct costs of other chronic condition in Brazilian populations, such as diabetes (USD 1,012) $)^{(44)}$, and non-melanoma skin cancer (BRL 1,172) $)^{(45)}$; but lower than rheumatoid arthritis (BRL 19,860.16) ${ }^{(46)}$. In addition, the results showed that drug treatment was the costliest component, accounting for $95.9 \%$ of total HCV costs; accordingly, a Brazilian study conducted prior to the incorporation of protease inhibitors have shown that drug treatment represented $88.2 \%$ of the total costs ${ }^{(47)}$.

We acknowledge some limitations of our study, mainly the possibility of missing data in the patients' medical records. Because it applies to all participants, it is unlikely to result in systematic bias among the different treatments or groups of patients. Secondly, some data were cross-sectionally obtained, which does not allow asserting a temporality between exposure and outcome. In addition, the study patients were from tertiary care centers; consequently, there are limitations regarding the understanding of the disease features in other levels of care. Thirdly, an important caveat is that new DAA prices decreased recently in the country, mainly within the Brazilian public healthcare system, what could lead to lower final costs in future analysis. Another important limitation is the fact that North and Midwest regions were not represented in the sample, which restricts the external validity of the results for the whole country. Finally, this study was conducted between 2014 and 2015 and since then new HCV treatments were made available in SUS, thus the costs exposed here may lack representativeness of currently available therapeutic strategies.

\section{CONCLUSION}

To our knowledge, this study presents the most detailed information on HCV Brazilian patients in a real-world setting. The results evidenced that most patients had cirrhosis, with high prevalence of cardiometabolic diseases, esophageal varices, reduced HRQoL mainly in terms of pain/discomfort, and work productivity impairment, especially presenteeism.

Additionally, we demonstrated that $\mathrm{HCV}$ imposes an economic burden on Brazilian Healthcare System, and that most of this cost is related to drug treatment. These results have strong implications for clinicians and policy makers, especially with the expanding of the availability of novel therapies in Brazil.

\section{ACKNOWLEDGEMENT}

AbbVie participated in the study design, planning and conduct, interpretation of data, review and approval of the content. All the authors had access to all relevant data and participated in data collection, interpretation, writing, review, and approval of this manuscript. Medical writing support and editorial support was provided by Leticia Dias, Pamela Santana, and Maíra Takemoto of ANOVA - Consultoria em Saúde Ltda and was funded by AbbVie.

\section{Authors' contribution}

The authors Castelo A, Brandão Mello EB, Teixeira R, Madruga JVR, Reuter T, Pereira LMMB, Silva GF, Alvares da Silva MR was were principal investigators. The author Zambrini $\mathrm{H}$ participated in the study design, planning, conduct and interpretation of data. The author Ferreira PRA performed the liver transient elastography (FibroScan).

\section{Departments where the work was performed}

Centro de Referência e Treinamento DST/AIDS, São Paulo. Universidade Federal de São Paulo. Universidade Estadual Paulista, Botucatu, São Paulo. Hospital Universitário Gafrée e Güinle, Rio de Janeiro. Universidade Federal de Minas Gerais, Faculdade de Medicina. Universidade Federal do Espírito Santo. Universidade Federal do Rio Grande do Sul, Hospital de Clínicas de Porto Alegre. Instituto do Fígado e Transplante de Pernambuco.

\section{Conflict of interests}

Castelo A: research grants received from BMS and AbbVie, travel grant received from Gilead and BMS.

Brandão Mello EB: speaker for and Consultant to AbbVie, Merck, Gilead, Janssen and BMS; member: National and State of Rio de Janeiro Committee of Viral Hepatitis and Liver Diseases.

Teixeira R: clinical research activities to BMS, AbbVie, Fiocruz/ Brazil; speaker Gilead, Bristol, Janssen, AbbVie, Fiocruz/Brazil.

Madruga JVR: participation in Advisory Boards for AbbVie, BMS, Gilead, GSK/ViiV and MSD; lectures for AbbVie, BMS, Gilead, GSK/ViiV, MSD, and Janssen; conduct clinical trials for AbbVie, BMS, Gilead, GSK/ViiV, MSD, and Janssen.

Reuter T: gilead speaker; researcher at NIH-START Study; GSK- principal investigator for the SAILING study.

Pereira LMMB: member of the MSD board, clinical research: MSD, Jansen, AbbVie; member of the Advisory Committee of the Viral Hepatitis Program (Ministry of Health).

Silva GF: companies for whom he provides consulting / medical education (last 5 years): MSD, Janssen, Bayer, Shering, Pharma, Roche, Bristol Myers-Squibb, Boehringer Ingelheim, AbbVie, Ferring, Gilead; Public service: Prof. of Gastroenterology of FMB-UNESP; Chief of the FMB Viral Hepatitis Clinic - UNESP; clinical research: MSD, Janssen, Roche, Bristol Myers - Squibb, AbbVie.

Alvares-da-Silva MR: classrooms, advisory board and/or clinical research for AbbVie, Alexion, Bayer, BMS, Fiocruz/Biomanguinhos, Eisai, Gilead, Janssen, Merck; member of the Advisory Committee on Viral Hepatitis and the National Technical Chamber of Liver Transplantation of the Ministry of Health of Brazil.

Zambrini H: AbbVie employee and may own AbbVie stock or stock options.

Ferreira PRA: clinical research activities: BMS, Janssen, AbbVie; speaker: Janssen, AbbVie, GSK, Gilead, BMS; support for medical education activities: Janssen, AbbVie, GSK, MSD; performing hepatic elastography by FibroScan in public and private medicine; Federal and state civil servant; Member of the SBI Viral Hepatitis Committee; member of the technical advisory committee of the State Program of Viral Hepatitis in São Paulo. 
Castelo A, Brandão Mello EB, Teixeira R, Madruga JVR, Reuter T, Pereira LMMB, Silva GF, Alvares-da-Silva MR, Zambrini H, Ferreira PRA. Hepatite C no sistema público de saúde brasileiro: impacto da doença. Arq Gastroenterol. 2018;55(4):329-37.

RESUMO - Contexto - A infecção pelo vírus da hepatite C (HCV) é uma das principais causas de hepatite C crônica e provoca implicações graves para pacientes, familiares e sistema de saúde. Objetivo - Os objetivos deste estudo foram: analisar a gravidade da fibrose hepática, comorbidades e complicações da hepatite C; examinar a qualidade de vida relacionada à saúde (QVRS), a perda de produtividade e o uso de recursos e custos no sistema público por pacientes brasileiros com hepatite $\mathrm{C}$ crônica, genótipo tipo 1. Métodos - Foi realizado um estudo transversal, multicêntrico em pacientes com hepatite C crônica genótipo-1 para avaliar a carga da doença no sistema público de saúde brasileiro entre novembro de 2014 e março de 2015. Os pacientes foram submetidos a uma elastografia hepática transitória (FibroScan) para avaliar a fibrose e a uma entrevista composta por um questionário desenvolvido para o estudo e cinco questionários padronizados: EQ-5D-3L, HCV-PRO, e WPAI:HepC. Resultados - Foram recrutados 313 pacientes. A amostra foi composta predominantemente por mulheres $(50,8 \%)$, caucasianos/brancos $(55,9 \%)$ e indivíduos empregados $(39,9 \%)$. A média de idade foi $56(\mathrm{DP}=10,4)$ anos. Em média, os pacientes com HCV esperaram 40,6 (DP=49,6) meses entre o diagnóstico e o primeiro tratamento. Ademais, 42,8\% dos pacientes que realizaram o FibroScan tinham cirrose; a comorbidade mais frequente foi doença cardiovascular (62,6\%) e a complicação mais comum as varizes esofágicas (54,5\%). Os resultados também mostraram que "dor e desconforto" foi a dimensão de QVRS mais afetada (55,0\% dos pacientes relataram alguns problemas) e que a média do escore do HCV-PRO foi 69,1 (DP=24,2). Em relação à perda de produtividade, o componente do WPAI:HepC mais afetado foi atividade diária $(23,5 \%)$ e entre os pacientes empregados, presenteísmo foi mais frequente do que absenteísmo (18,5\% vs 6,5\%). Os custos diretos médicos totais com essa amostra foi de 12.305,72USD por paciente em um período de dois anos; o tratamento medicamentoso representou $95 \%$ desse total. Conclusão - Esse estudo mostrou a maioria dos pacientes possui cirrose, apresenta alta prevalência de doenças cardiometabolicas e varizes esofágicas, QVRS reduzida principalmente em termos de dor/desconforto e dano na produtividade, especialmente presenteísmo. Adicionalmente, nós demonstramos que o HCV impõe uma carga econômica no sistema de saúde brasileiro e que os medicamentos correspondem à maioria dos custos.

DESCREITORES - Hepatite C. Cirrose hepática. Qualidade de vida. Efeitos psicossociais da doença.

\section{REFERENCES}

1. Hagan LM, Schinazi RF. Best strategies for global HCV eradication. Liver Int 2013;33 (Suppl 1):68-79.

2. Pereira LMMB, Martelli CMT, Moreira RC, Merchan-Hamman E, Stein AT, Cardoso MR, et al. Prevalence and risk factors of Hepatitis $\mathrm{C}$ virus infection in Brazil, 2005 through 2009: a cross-sectional study. BMC Infect Dis. 2013;13:60.

3. European Association for the Study of the Liver. EASL Clinical Practice Guidelines: Management of hepatitis C virus infection. J Hepatol. 2014;60: 392-420.

4. Younossi ZM, Birerdinc A, Henry L. Hepatitis C infection: A multi-faceted systemic disease with clinical, patient reported and economic consequences. J Hepatol. 2016;65:S109-19.

5. Messina JP, Humphreys I, Flaxman A, Brown A, Cooke GS, Pybus OG, et al. Global distribution and prevalence of hepatitis $\mathrm{C}$ virus genotypes. Hepatology. 2015;61:77-87.

6. Campiotto S, Pinho JRR, Carrilho FJ, Da Silva LC, Souto FJD, Spinelli V, et al. Geographic distribution of hepatitis C virus genotypes in Brazil. Braz J Med Biol Res. 2005;38:41-9.

7. Chen SL, Morgan TR. The natural history of hepatitis C virus (HCV) infection Int J Med Sci. 2006;3:47-52

8. Westbrook RH, Dusheiko G. Natural history of hepatitis C. J Hepatol. European Association for the Study of the Liver. 2014;61(Suppl 1):S58-68.

9. Lavanchy D. The global burden of hepatitis C. Liver Int. 2009;29(Suppl 1):74-81.

10. U.S. Department of Health \& Human Services. Centers for Disease Control and Prevention. 2014.

11. Naveira M, Barbosa J, Sereno L, Domanico A, Mesquita F, de Souza LA. 12 Years of Universal Access to Hepatitis C Treatment. J Int Assoc Provid AIDS Care. 2014;13:560-7.

12. Mesquita F, Santos ME, Benzaken A, Corrêa RG, Cattapan E, Sereno LS, et al. The Brazilian comprehensive response to hepatitis $\mathrm{C}$ : from strategic thinking to access to interferon-free therapy. BMC Public Health. 2016;16:1132.

13. Brasil. Ministério da Saúde. Secretaria de Vigilância em Saúde. Departamento de DST Aids e Hepatites Virais. Protocolo Clínico e Diretrizes Terapêuticas para Hepatite C e Coinfecções. Série A. Normas e Manuais Técnicos. Brasília-DF; 2015

14. Brasil. Ministério da Saúde. Secretaria de Vigilância em Saúde. Departamento de DST Aids e Hepatites Virais. Protocolo Clínico e Diretrizes Terapêuticas para Hepatite C e Coinfecções. Brasília-DF; 2017.

15. World Health Organization (WHO). Guidelines for the screening, care and treatment of persons with hepatitis C infection. 2014.
16. Reneen V, Oppe M. EQ-5D User Guide version 5.1. 2015

17. Anderson RT, Baran RW, Erickson P, Revicki D, Dietz B, Gooch K. Psychometric evaluation of the hepatitis C virus patient-reported outcomes (HCV-PRO) instrument: validity, responsiveness, and identification of the minimally important difference in a phase 2 clinical trial. Qual Life Res. 2014;23:877-86.

18. Reilly MC, Zbrozek AS, Dukes EM. The validity and reproducibility of a work productivity and activity impairment instrument. Pharmacoeconomics. 1993; 4:353-65.

19. Dolan P. Modeling Valuations for EuroQol Health States Valuations Modeling Med Care. 1997;35:1095-108

20. Brasil. Ministério da Saúde. SIGTAP - Sistema de Gerenciamento da Tabela de Procedimentos, Medicamentos e OPM do SUS [Internet]. 2012 [Cited 2005 May 20]. p. 2. Available from: http://sigtap.datasus.gov.br/tabela-unificada/app/ sec/inicio.jsp

21. Brasil. Sistema de Informação Hospitalar do Sistema Único de Saúde - SIH/SUS [Internet]. 2016. Available from: http://datasus.saude.gov.br/sistemas-e-aplicativos/ hospitalares/sihsus

22. Ministério da Saúde. Secretaria de Ciência T e IE. Banco de Preçoos em Saúde - BPS [Internet]. [Cited 2016 Jan 1]. Available from: http://portal.saude.gov.br/ bps/visao/consultapublica/index.cfm

23. Brasil. Câmara de Regulação do Mercado de Medicamentos - CMED [Internet] [Cited 2016 Jan 1]. Available from: http://portal.anvisa.gov.br/listas-de-precos

24. Centro Colaborador da OMS para a Classificação de Doenças em Português (Centro Brasileiro de Classificação de Doenças). CID - 10 Classificação Estatística Internacional de Doenças e Problemas Relacionados à Saúde. 2008.

25. Brasil. Ministério da Saúde. Secretaria de Vigilância em Saúde. Departamento de DST Aids e Hepatites Virais. Protocolo Clínico e Diretrizes Terapêuticas (PCDT) para Hepatite Viral C e Coinfecções: manejo do paciente infectado cronicamente pelo genótipo 1 do HCV e fibrose avançada: Brasília-DF; 2013.

26. World Health Organization (WHO). Collaborating Centre for Drug Statistics Methodology. 2016.

27. Poynard T, Bedossa P, Opolon P. Natural history of liver fibrosis progression in patients with chronic hepatitis C. The OBSVIRC, METAVIR, CLINIVIR, and DOSVIRC groups. Lancet. 1997;349:825-32.

28. Sebastiani G, Gkouvatsos K, Pantopoulos K. Chronic hepatitis C and liver fibrosis. World J Gastroenterol. 2014;20:11033-53.

29. Fernandes FF, Ferraz ML, Andrade LE, Dellavance A, Terra C, Pereira G, et al Enhanced liver fibrosis panel as a predictor of liver fibrosis in chronic hepatitis C patients. J Clin Gastroenterol. 2015;49:235-41. 
30. Carvalho-Filho RJ, de Lucca Schiavon L, Narciso-Schiavon JL, Sampaio JP, Lanzoni VP, Gomes Ferraz ML, et al. Clinical and histological impact of previous hepatitis B virus infection in patients with chronic hepatitis C. Liver Int. 2009;29:133-40.

31. Moia, LJMP; Amaral, ISA; Farias AJL SM. Infecção Pelo Vírus Da Hepatite C Em Hospital de Referência na Amazônia Brasileira. Rev Para Med. 2014;28(3).

32. Gill K, Ghazinian H, Manch R, Gish R. Hepatitis C virus as a systemic disease: reaching beyond the liver. Hepatol Int. Springer India. 2015;1-9.

33. Stewart B, Mikocka-Walus A, Morgan J, Colman A, Phelps M, Harley H, et al. Anxiety and depression in Australian chronic hepatitis C outpatients: prevalence and predictors. Australas Psychiatry. 2012;20:496-500.

34. He Huang, Kang R, Zhao Z. Hepatitis C Virus Infection and Risk of Stroke: A Systematic Review and Meta-Analysis. Wong VW-S, editor. PLoS One. 2013;8:e81305.

35. Grasso A, Malfatti F, Testa R. Are metabolic factors still important in the era of direct antiviral agents in patients with chronic hepatitis C? World J Gastroenterol 2013;19:6947-56

36. Ampuero J, Romero-Gómez M. Assessing cardiovascular risk in hepatitis C: an unmet need. World J Hepatol. 2015;7:2214-9.

37. Modabbernia A, Poustchi H, Malekzadeh R. Neuropsychiatric and psychosocial issues of patients with hepatitis $\mathrm{C}$ infection: a selective literature review. Hepat Mon. 2013;13:1-9.

38. Chong CAKY, Gulamhussein A, Heathcote EJ, Lilly L, Sherman M, Naglie $\mathrm{G}$, et al. Health-state utilities and quality of life in hepatitis C patients. Am J Gastroenterol. 2003;98:630-8.
39. Samp JC, Perry R, Piercy J, Wood R, Baran RW. Patient health utility, work productivity, and lifestyle impairment in chronic hepatitis $\mathrm{C}$ patients in France. Clin Res Hepatol Gastroenterol. 2015;39:307-14.

40. Andrade MV, Maia AC, Noronha KVMDS, Kind P. What matters most ? Evidence-based findings of health dimensions affecting the societal preferences for EQ-5D health states. Cad Saúde Pública. 2013;29:59-72.

41. Manne V, Sassi K, Allen R, Saab S. Hepatitis C and work impairment: a review of current literature. J Clin Gastroenterol. 2014;48:595-9.

42. DiBonaventura M daCosta, Wagner J-S, Yuan Y, L'Italien G, Langley P, Ray Kim W. The impact of hepatitis $\mathrm{C}$ on labor force participation, absenteeism, presenteeism and non-work activities. J Med Econ. 2011;14:253-61.

43. Vargas ACC. A problemática da participação no âmbito institucional das Organizações Não-Governamentais: uma perspectiva psicanalística de sujeito, grupos e instituições. Universidade de São Paulo; 2012.

44. Borges NB, Ferraz MB, Chacra AR. The cost of type 2 diabetes in Brazil: evaluation of a diabetes care center in the city of São Paulo, Brazil. Diabetol Metab Syndr. 2014;6:122.

45. De Souza RJSP, Mattedi AP, Corrêa MP, Rezende ML, Ferreira ACA. An estimate of the cost of treating non-melanoma skin cancer in the state of São Paulo, Brazil. An Bras Dermatol. 2011;86:657-62.

46. Buendgens FB, Blatt CR, Marasciulo ACE, Leite SN, Farias MR. Estudo de custo-análise do tratamento da artrite reumatoide grave em um município do Sul do Brasil. Cad Saude Publica. 2013;29(Suppl 1):s81-91.

47. Blatt CR, Bernardo NLMDC, Rosa JA, Bagatini F, Alexandre RF, Balbinotto Neto G, et al. An Estimate of the Cost of Hepatitis C Treatment for the Brazilian Health System. Value Heal Reg Issues. 2012;1:129-35. 